\title{
Influence of the Composition of the Hank's Balanced Salt Solution on the Corrosion Behavior of AZ31 and AZ61 Magnesium Alloys
}

\author{
Jakub Tkacz ${ }^{1,2, *}$ (D), Karolína Slouková ${ }^{1}$, Jozef Minda ${ }^{1}$, Juliána Drábiková ${ }^{1}$, \\ Stanislava Fintová ${ }^{1,3}$, Pavel Doležal ${ }^{1,4}$ and Jaromír Wasserbauer ${ }^{1}$ \\ 1 Materials Research Centre, Faculty of Chemistry, Brno University of Technology, 61200 Brno, \\ Czech Republic; xcsloukova@fch.vut.cz (K.S.); xcminda@fch.vut.cz (J.M.); xcdrabikovaj@fch.vut.cz (J.D.); \\ fintova@ipm.cz (S.F.); dolezal@fme.vutbr.cz (P.D.); wasserbauer@fch.vut.cz (J.W.) \\ 2 Research Centre, University of Žilina, 01008 Žilina, Slovakia \\ 3 Institute of Physics of Materials AS CR v. v. i., Žižkova 22, 61662 Brno, Czech Republic \\ 4 Institute of Materials Science and Engineering, Faculty of Mechanical Engineering, \\ Brno University of Technology, Technická 2896/2, 61669 Brno, Czech Republic \\ * Correspondence: tkacz@fch.vut.cz; Tel.: +420-54-114-9469
}

Received: 31 August 2017; Accepted: 25 October 2017; Published: 1 November 2017

\begin{abstract}
The electrochemical corrosion characteristics of AZ31 and AZ61 magnesium alloys were analyzed in terms of potentiodynamic tests and electrochemical impedance spectroscopy. The influence of the solution composition and material surface finish was examined also through the analysis of corrosion products created on the samples' surface after electrochemical measurements in terms of scanning electron microscopy using energy-dispersive spectroscopy. Obtained data revealed the differences in the response of the magnesium alloys to enriched Hank's Balanced Salt Solution-HBSS+ (with $\mathrm{Mg}^{2+}$ and $\mathrm{Ca}^{2+}$ ions) and Hank's Balanced Salt Solution-HBSS (without $\mathrm{Mg}^{2+}$ and $\mathrm{Ca}^{2+}$ ions). Both examined alloys exhibited better corrosion resistance from the thermodynamic and kinetic point of view in the enriched HBSS+. AZ61 magnesium alloy reached higher values of polarization resistance than AZ31 magnesium alloy in both the used corrosion solutions. Phosphate-based corrosion products were characteristic for the AZ31 and AZ61 alloys tested in the HBSS (without $\mathrm{Mg}^{2+}$ and $\mathrm{Ca}^{2+}$ ions). The combination of phosphate-based corrosion products and clusters of $\mathrm{MgO}$ and $\mathrm{Mg}(\mathrm{OH})_{2}$ was typical for the surface of samples tested in the enriched HBSS+ (with $\mathrm{Mg}^{2+}$ and $\mathrm{Ca}^{2+}$ ions). Pitting corrosion attack was observed only in the case of enriched HBSS+.
\end{abstract}

Keywords: magnesium alloy; AZ31; AZ61; HBSS; HBSS+; EIS; potentiodynamic test

\section{Introduction}

Magnesium is an essential element for living organisms, however, for technical purposes is the magnesium used mainly in the form of alloys. Alloying elements improve magnesium mechanical properties and it can be used to control its reactivity. Due to the suitable combination of physico-mechanical properties, biocompatibility and non-toxicity specific magnesium alloys are investigated for medical applications. In the case of orthopedic implants physical and mechanical properties of magnesium alloys are also important. These properties are similar to the properties of a human bone (e.g., density, compressive yield strength, ultimate tensile strength). Magnesium alloy implants are moreover biocompatible and biodegradable [1-11]. As a result of chemical reactions with the biological environment non-toxic corrosion products are created on the surface of the implants. In the human body the magnesium alloy implants dissolve and are absorbed, which prevents surgical 
removal of the implants after tissue healing [5,6]. The disadvantage of magnesium and magnesium alloys is their high reactivity at the physiological $\mathrm{pH}$ (7.4-7.6) as well as in physiological media containing high concentrations of chloride ions, which could cause rapid disintegration of the implant in the biological environment $[7,8]$. Furthermore, during the corrosion process of magnesium and its alloys, the release of hydrogen gas may be too fast to be endured by the host tissues [9].

One way to influence corrosion resistance and mechanical properties of magnesium alloys is by using high purity alloys that maintain metal impurities such as iron, nickel and copper below limits. Examples of alloying elements of magnesium alloys for biodegradable implants for improvement of the corrosion resistance of the alloys are calcium, zinc, etc. [10-15]. On the other hand, even the magnesium alloys for medical applications have to have good mechanical properties and they have to also contain other alloying elements. One of the basic alloying elements for magnesium mechanical and corrosion properties improvement is aluminum. Even though Al has a positive effect on magnesium alloys properties, the amount of $\mathrm{Al}$ added must be controlled in the case of alloys for medical applications. A high concentration of Al was considered to possibly cause neurotoxic illnesses such as dementia or Alzheimer's disease. However, when $\mathrm{Al}$ is introduced into the human body in small concentrations, for instance during dietary ingestion or consumption from natural or urban water supplies, then it is naturally excreted through urine or in the form of bile [10,16-21].

Hank's balanced salt solutions (HBSSs), which are one of the options for simulating the corrosive environment of the body of living organisms are often used for analysis of the corrosion behavior of magnesium alloys that are expected to be used in medicine applications. Mainly due to higher chloride concentrations, HBSSs are more aggressive medium compared to artificial plasma. Sulfate ions contained in HBSS can also result in higher corrosion rate of magnesium and its alloys compared to other corrosion media used for material corrosion properties characterization [22-31].

The reactivity of material in the corrosion environment is, besides many aspects, influenced with the chemical and phase composition of the material and chemical composition of the testing solution.

Electrochemical corrosion behavior of wrought AZ31 and AZ61 alloys in HBSS characterized by Tkacz et al. in [32] revealed different response of the materials due to their chemical and phase composition and surface finish. Based on the EIS (electrochemical impedance spectroscopy) measurement results, AZ61 magnesium alloy was considered as more corrosion resistant when compared to AZ31 magnesium alloy, while opposite conclusion can be considered based on the potentiodynamic test results. Potentiodynamic tests revealed minor influence of the surface finish in the case of AZ31 magnesium alloy represented for example by corrosion potential $\left(E_{\text {corr }}\right)$ values. The samples with polished surface $\left(E_{\text {corr }}=-1.676 \pm 0.003 \mathrm{~V}\right)$ were characteristic with more positive value of $E_{\text {corr }}$ comparing to the ground samples $\left(E_{\text {corr }}=-1.701 \pm 0.003 \mathrm{~V}\right)$. On the other hand, no influence of surface finish was observed in the case of AZ61 magnesium alloy $\left(E_{\text {corr }}=-1.708 \pm 0.004 \mathrm{~V}\right.$ for ground sample and $E_{\text {corr }}=-1.708 \pm 0.003 \mathrm{~V}$ for polished sample). No significant influence of surface finish was observed based on the EIS test results. The increase of polarization resistance up to $24 \mathrm{~h}$ of immersion of the samples in the HBSS to the values of approximately $4000 \Omega \cdot \mathrm{cm}^{2}$ was characteristic for both the surface states of AZ31 magnesium alloy, while increasing exposure time to the corrosion environment did not have any significant influence on the polarization resistance and the value remained stable. In the case of AZ61 magnesium alloy a significant increase of the values of polarization resistance up to the $48 \mathrm{~h}$ of exposure of the samples to the corrosion environment was observed for both the material states, reaching the value of polarization resistance of approximately $9000 \Omega \cdot \mathrm{cm}^{2}$. Following an increase of immersion time resulted in an additional increase of the $R_{\mathrm{p}}$ to the value of approximately $21,000 \Omega \cdot \mathrm{cm}^{2}$ for ground and $17,000 \Omega \cdot \mathrm{cm}^{2}$ for polished samples.

The influence of the chloride ions on corrosion behavior of $\mathrm{Mg}-\mathrm{Al}-\mathrm{Zn}$ based alloys was reported in several studies. Ambat et al. studied in [33] the influence of chloride ion concentration and $\mathrm{pH}$ on the corrosion and electrochemical behavior of die-cast and ingot-cast AZ91D alloy. The effect of chloride ion concentration was studied in $\mathrm{NaCl}(0-10 \%)$ solutions at $\mathrm{pH} 7.25$. The effect of $\mathrm{pH}$ was 
analyzed in solutions with the chloride ion concentration kept constant at 3.5\% while the $\mathrm{pH}$ was varied from 1.0-12.0. Material behavior was analyzed with immersion and potentiodynamic testing. Increase in chloride ion concentration increased the corrosion rate of AZ91D magnesium alloy at $\mathrm{pH} 7.25$ and 12.0 for both the material states, however, at $\mathrm{pH} 2.0$, the effect of chloride ion was found to be negligible. High corrosion rate was observed for both the material states in highly acidic solutions, while the corrosion rate was found to be low in neutral $\mathrm{pH}$ and alkaline conditions. The corrosion rate determined from immersion tests was much higher than that obtained from electrochemical measurements. The observation was attributed to the negative difference effect and to the physical removal of $\beta$ phase during corrosion. The differences between the response of material states to the corrosion environment were discussed in terms of microstructural differences.

The effect of chloride ion concentration and $\mathrm{pH}$ on the corrosion (immersion tests) and electrochemical behavior (potentiodynamic tests) of AZ63 alloy were studied in $\mathrm{NaCl}$ solutions at different concentrations $(0.01,0.2,0.6,1$ and $2 \mathrm{M})$ and $\mathrm{pH}$ values $(2,3,8,11$ and 11.5$)$ were studied by Altun and Sen in [34]. Authors observed that the corrosion rate increased with the increase in concentration of $\mathrm{NaCl}$ solution. However, it was observed, that with the increase in chloride ion concentration, the rising rate of corrosion rate decreased. The corrosion rate increase with increasing chloride ion concentration was attributed to the participation of chloride ions in the dissolution reaction. Chloride ions are aggressive for both magnesium and aluminum. The adsorption of chloride ions to oxide covered magnesium surface transforms $\mathrm{Mg}(\mathrm{OH})_{2}$ to easily soluble $\mathrm{MgCl}_{2}$. Authors also observed a shift of the corrosion potential to more negative (more active) values with the increase in chloride ion concentration. The explanation for this behavior was found in adsorption of these ions on the alloy surface at weak parts of the oxide film. Corrosion potential was observed to be shifted to more negative (more active) values with the decrease in $\mathrm{pH}$ value of the solution. Higher $\mathrm{pH}$ values were discussed to favor the formation of $\mathrm{Mg}(\mathrm{OH})_{2}$ which protects the alloy from corrosion.

Merino et al. studied in [35] the influence of chloride ion concentration and temperature on the corrosion of $\mathrm{Mg}-\mathrm{Al}$ alloys in a salt fog with the focus on the effect of $\mathrm{Al}$ content in the alloy. The results of their investigation showed that the corrosion attack of Mg, AZ31, AZ80 and AZ91D materials under the salt fog test increases with increasing temperature and chloride anion concentration, while the effect of temperature was considered to be more noticeable than that of chloride concentration. Authors also analyzed the influence of the $\mathrm{Al}$ content and resulting presence of intermetallic phases on material corrosion behavior. In the case of the wrought AZ31 only negligible influence of the present AlMn based phase was observed, while in the case of cast AZ80 and AZ91 alloys the creation of galvanic couples between $\mathrm{Al}-\mathrm{Mn}$ and $\beta-\mathrm{Mg}_{17} \mathrm{Al}_{12}$ phases with the $\mathrm{Mg}$ matrix resulted in more pronounced corrosion attack. Authors also observed the influence of the distribution, size and morphology of the $\beta$ phase and resulting Al-rich corrosion products layer created on the material surface during the corrosion.

Influence of sulfate anion concentration and $\mathrm{pH}$ on the corrosion of Mg-Al-Zn-Mn (GA9) magnesium alloy was investigated by Shetty et al. [36]. The studies were carried out in sodium sulfate solutions with concentrations range of $0.1-2 \mathrm{M}$; and at different temperatures of $30-50{ }^{\circ} \mathrm{C}$ and $\mathrm{pH}$ of 3.0-12.0. According to the experimental data, the corrosion rate of the alloy increased with the increase in temperature, and also with the increase in the concentration of sodium sulfate in the medium. It was observed that the rate of corrosion decreased with the increase in $\mathrm{pH}$.

Even thought, magnesium alloys corrosion properties are widely investigated, most of the studies are performed in $\mathrm{NaCl}$ and $\mathrm{Na}_{2} \mathrm{SO}_{4}$ solutions simulating corrosion environment in engineering applications [33-36]. Corrosion behavior of magnesium alloys was studied in several types of HBSS [22-32], however, the influence of the chemical composition of HBSS on corrosion processes is not available in the literature according to the authors' knowledge.

Corrosion characteristics of metallic materials can be analyzed in different ways. In this work, electrochemical methods have been used to investigate the corrosion behavior of magnesium alloys. Potentiodynamic tests and electrochemical impedance spectroscopy were used for the description of 
the material response to the HBSS and enriched HBSS+. Obtained data were discussed with the aim to identify the influence of material chemical and phase composition, surface roughness and composition of the corrosion solution on corrosion behavior. Values of corrosion potential ( $\left.E_{\text {corr }}\right)$ expressing thermodynamics of the corrosion process and corrosion current density values $\left(i_{\text {corr }}\right)$ expressing the kinetic of the corrosion process were obtained by potentiodynamic measurements. Corrosion potential characteristic for the material expresses the thermodynamic stability of the system and the conditions for material corrosion and its resistance against corrosion process. Kinetic of the corrosion process can be shown by the evolution of the corrosion rate $\left(v_{\text {corr }}\right)$ which can be calculated from the $i_{\text {corr }}$. Polarization resistance $\left(R_{\mathrm{p}}\right)$ values were obtained by electrochemical impedance spectroscopy (EIS). Evolution of the corrosion products on the specimen surface was analyzed in terms of scanning electron microscopy and correlated with the composition of the used corrosion solution.

The presented results show differences in electrochemical corrosion behavior of AZ31 and AZ61 alloys in HBSS and enriched HBSS+ with the aim to characterize material behavior and different response of ground and polished materials on the different chemical composition of the corrosion solution.

\section{Materials and Methods}

\subsection{Material}

Wrought AZ31 and AZ61 magnesium alloys plates were used for the experiments. Metallographic analysis and verification of chemical composition of the magnesium alloys were performed by scanning electron microscope (SEM) (ZEISS EVO LS 10, Cambridge, UK) with energy dispersive spectrometer (EDS) (OXFORD Instruments X-MAX $80 \mathrm{~mm}^{2}$, Abingdon, UK). Metallographic samples for microstructural analysis were prepared in terms of a conventional procedure consisting of grinding, polishing (diamond paste $1 \mu \mathrm{m}$ ) and etching (picral solution [37]).

\subsection{Electrochemical Measurements}

Wrought AZ31 and AZ61 alloys plates were cut to samples with dimensions of $20 \times 20 \times 2 \mathrm{~mm}^{3}$. One batch of the samples of each magnesium alloy was ground with 1200 grit SiC paper with a particle size of $\sim 15 \mu \mathrm{m}$ (marked \#1200) and the second batch was additionally polished with diamond pastes up to $0.25 \mu \mathrm{m}$ (marked $0.25 \mu \mathrm{m}$ ). Wetting agent during polishing was isopropyl alcohol.

Electrochemical characteristics of the ground and polished samples were measured by potentiostat/galvanostat BioLogic VSP-300 (BioLogic, Seyssinet-Pariset, France). Three-electrode system was used for electrochemical measurements, where the magnesium alloy sample served as a working electrode (WE), saturated calomel electrode (SCE) was used as a reference electrode (RE) and platinum gauze was used as a counter electrode (CE). Used corrosion environment was enriched HBSS+ (with the addition of $\mathrm{Mg}^{2+}$ and $\mathrm{Ca}^{2+}$ ions) and HBSS (without $\mathrm{Mg}^{2+}$ and $\mathrm{Ca}^{2+}$ ions) from [32] was used to show the dependence of the response of the magnesium alloys on corrosion solution composition. Experiments were performed at the temperature of $37 \pm 1^{\circ} \mathrm{C}$. The composition of the used HBSS and enriched HBSS+ is given in Table 1 . An area of $1.0 \mathrm{~cm}^{2}$ of the sample was exposed to the corrosion environment during the electrochemical testing. The stabilization time of the sample exposed to the corrosion environment before the measurement was $5 \mathrm{~min}$. Each electrochemical measurement was performed on three specimens with adequate surface finish.

Table 1. Chemical composition of HBSS and enriched HBSS+ used in [32].

\begin{tabular}{ccccccccc}
\hline \multirow{2}{*}{ Solutions } & \multicolumn{7}{c}{ Composition $\left(\mathbf{m g} \cdot \mathbf{d m}{ }^{-3}\right)$} \\
\cline { 2 - 9 } & $\mathbf{N a C l}$ & $\mathbf{K C l}$ & $\mathbf{K H}_{\mathbf{2}} \mathbf{P O}_{\mathbf{4}}$ & Glucose & $\mathbf{N a}_{\mathbf{2}} \mathbf{H P O}_{\mathbf{4}}$ & $\mathbf{\mathbf { M g S O } _ { 4 }}$ & $\mathbf{C a C l}_{\mathbf{2}}$ & $\mathbf{N a}_{\mathbf{2}} \mathbf{C O}_{\mathbf{3}}$ \\
\hline HBSS & 8000 & 400 & 60 & 1000 & 48 & - & - & 350 \\
Enriched HBSS+ & 8000 & 400 & 60 & 1000 & 48 & 98 & 140 & 350 \\
\hline
\end{tabular}


Potentiodynamic measurements were performed by polarizing of the sample surface in the range from $-100 \mathrm{mV}$ to $+200 \mathrm{mV}$ vs. open circuit potential $\left(E_{\mathrm{OCP}}\right)$. Scan rate was $1 \mathrm{mV} \cdot \mathrm{s}^{-1}$.

Electrochemical impedance spectroscopy (EIS) measurements were performed after exposure of the sample surface to the enriched HBSS+ with $\mathrm{Mg}^{2+}$ and $\mathrm{Ca}^{2+}$ ions for $5 \mathrm{~min}, 1,2,4,8,12,24,48,72$, 96 and $168 \mathrm{~h}$. EIS scan frequency ranged from $100 \mathrm{kHz}$ to $100 \mathrm{mHz}$, and the perturbation amplitude was $5 \mathrm{mV}$.

With the aim to determine the influence of the enriched HBSS+ with $\mathrm{Mg}^{2+}$ and $\mathrm{Ca}^{2+}$ ions on the experimental material electrochemical corrosion behavior were the EIS measurements performed also in the solution not containing addition $\mathrm{Mg}^{2+}$ and $\mathrm{Ca}^{2+}$ ions (Table 1).

The chemical composition of the corrosion products created on the surface of the AZ31 and AZ61 alloys during EIS measurements was analyzed with SEM ZEISS EVO LS 10 with EDS OXFORD Instruments X-MAX $80 \mathrm{~mm}^{2}$. The samples were rinsed with isopropyl alcohol and dried with air before the analysis.

\section{Results}

\subsection{Microstructural Analysis}

The microstructure of the AZ31 magnesium alloy is consisted of polyhedral grains of the substitutional solid solution $\alpha-\mathrm{Mg}$ in which AlMn intermetallic phase particles were observed (Figure 1) [38-40]. The distribution of the basic alloying elements revealed with the mapping mode by EDS is shown in Figure 1. The chemical composition of the AZ31 magnesium alloy verified by EDS is provided in Table 2. The content of the main alloying elements ( $\mathrm{Al}, \mathrm{Zn}$ and $\mathrm{Mn}$ ) agrees with the standard ASTM B90M [41].
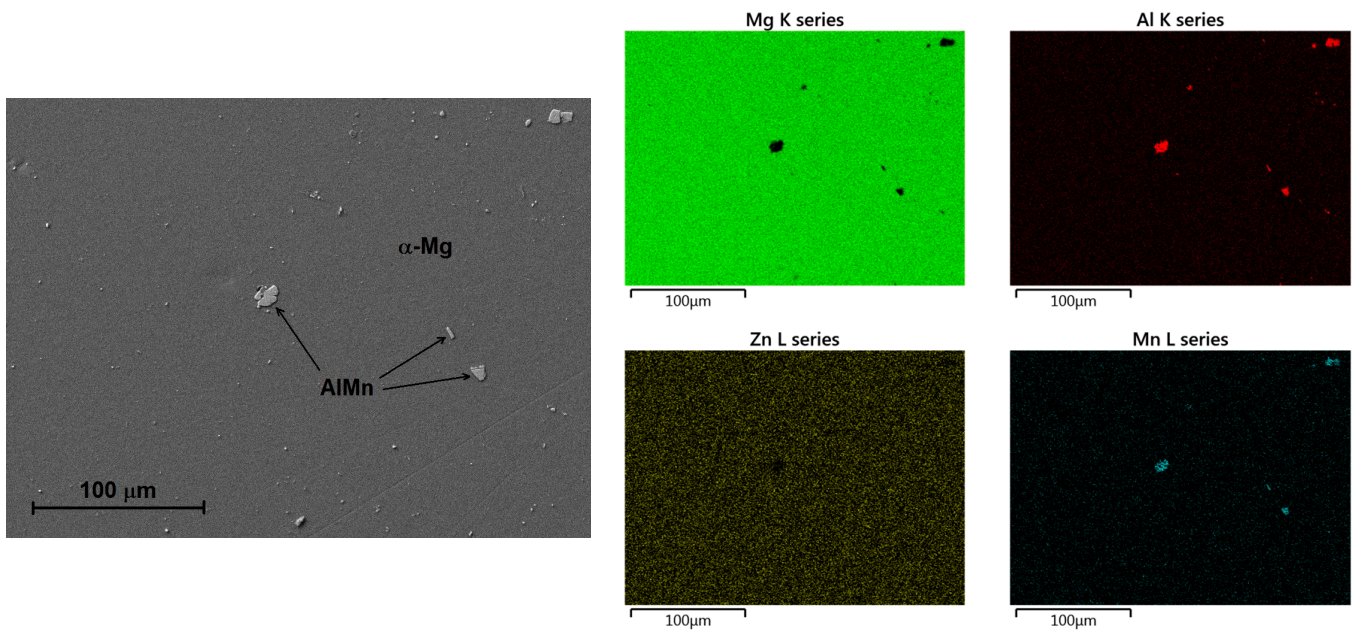

Figure 1. Microstructure of AZ31 magnesium alloy SEM (Scanning Electron Microscope) with EDS (Energy Dispersive Spectrometer) maps of the elements distribution: magnesium (Mg), aluminum (Al), zinc $(\mathrm{Zn})$ and manganese $(\mathrm{Mn})$.

Table 2. Chemical composition of AZ31 magnesium alloy (EDS: Energy Dispersive Spectrometer).

\begin{tabular}{ccccc}
\hline Element & Al & Zn & Mn & Mg \\
\hline Chemical composition (wt \%) & 3.2 & 0.9 & 0.4 & balance \\
\hline
\end{tabular}

The microstructure of the AZ61 magnesium alloy is consists of polyhedral grains of the substitution solid solution $(\alpha-\mathrm{Mg}), \beta$-phase (particles of $\mathrm{Mg}_{17} \mathrm{Al}_{12}$ intermetallic phase) and $\mathrm{AlMn}$ intermetallic phase particles (Figure 2). The EDS mapping mode was used for the investigation of the distribution of the basic alloying elements in the alloy (Figure 2). The chemical composition of the 
AZ61 magnesium alloy was verified by EDS (Table 3). The content of the main alloying elements (Al, $\mathrm{Zn}$ and Mn) agrees with the standard ASTM B107M [42].
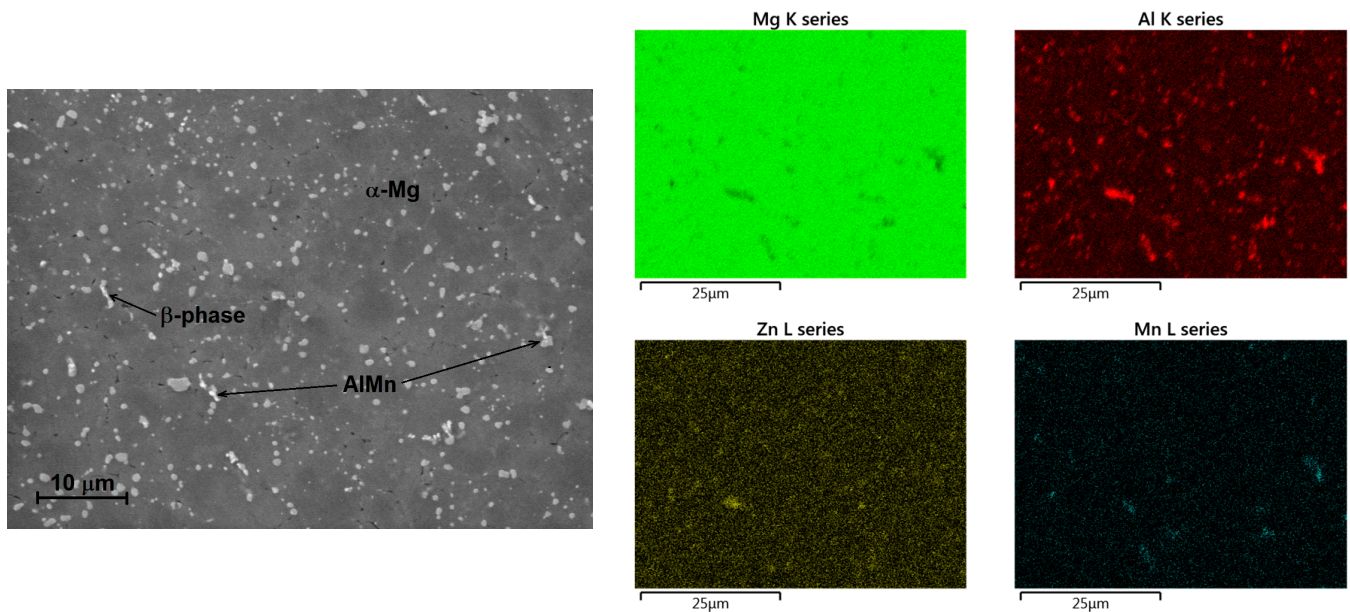

Figure 2. Microstructure of AZ61 magnesium alloy (SEM) with EDS maps of the elements distribution: magnesium $(\mathrm{Mg})$, aluminum $(\mathrm{Al})$, zinc $(\mathrm{Zn})$ and manganese $(\mathrm{Mn})$.

Table 3. Chemical composition of AZ61 magnesium alloy (EDS).

\begin{tabular}{ccccc}
\hline Element & Al & Zn & Mn & Mg \\
\hline Chemical composition (wt \%) & 6.0 & 0.7 & 0.3 & balance \\
\hline
\end{tabular}

\subsection{Potentiodynamic Measurements}

Figure 3 shows typical potentiodynamic curves obtained with linear polarization of ground and polished samples of AZ31 and AZ61 alloys. The pitting corrosion attack of all the tested samples was revealed by an increase of current density at the anodic branch of the curves which belongs to the value of pitting potential $\left(E_{\mathrm{pit}}\right)$ [38]. The values of the corrosion current density $\left(i_{\text {corr }}\right)$ for the AZ31 magnesium alloy were determined only from the cathodic branch of the polarization curves applying the Tafel extrapolation. The Tafel region for the anodic branches of the potentiodynamic curves characterizing AZ31 magnesium alloy was insufficient to use the Tafel extrapolation to obtain relevant values of $i_{\text {corr }}$, following the rule that the plane region has to be at least $50 \mathrm{mV}$ [38] from the $E_{\text {corr }}$. On the other hand, $i_{\text {corr }}$ values for the AZ61 magnesium alloy were determined from both the branches of the obtained polarization curves applying Tafel extrapolation.
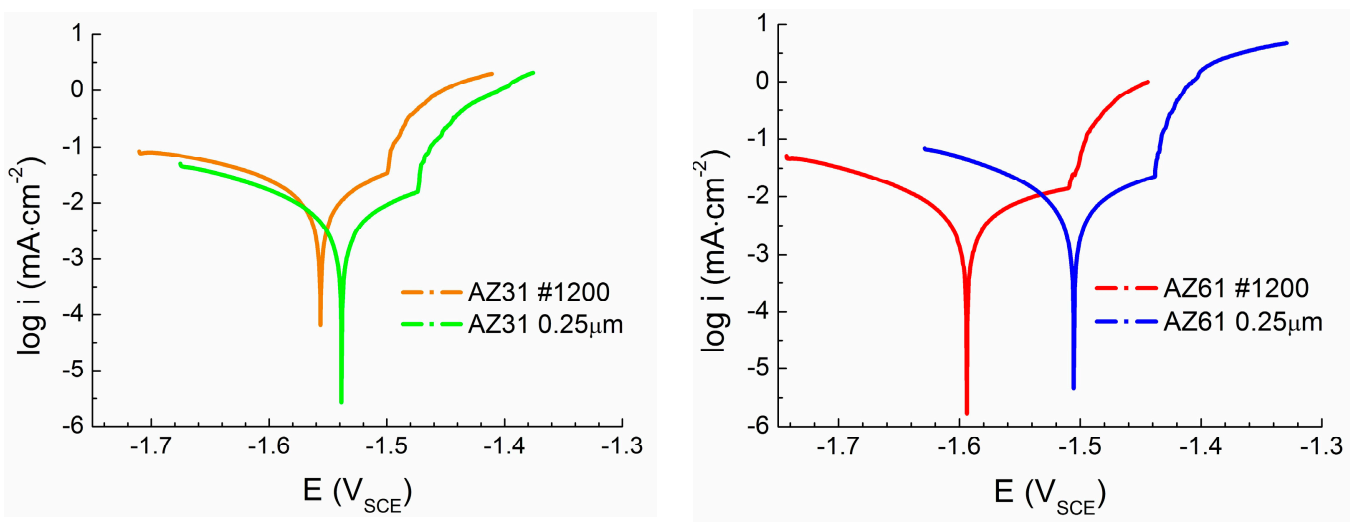

Figure 3. Potentiodynamic curves of ground (\#1200) and polished $(0.25 \mu \mathrm{m})$ surface of AZ31 and AZ61 magnesium alloys in enriched HBSS+ (with $\mathrm{Mg}^{2+}$ and $\mathrm{Ca}^{2+}$ ions). 
For both the tested materials the finer surface (polishing with $0.25 \mu \mathrm{m}$ diamond paste) resulted in the potentiodynamic curve shift to more positive values of potential comparing to the curves characterizing the ground samples.

The electrochemical characteristics estimated by potentiodynamic measurements: $E_{\mathrm{OCP}}, E_{\text {corr }}$, $E_{\text {pit }}, i_{\text {corr }}$ and corrosion rate $v_{\text {corr }}$ are given in Table 4 . From the obtained data, a larger influence of the surface finish can be observed in the case of AZ61 magnesium alloy when compared to the AZ31 magnesium alloy.

Table 4. Results of potentiodynamic tests performed in enriched HBSS+ (with $\mathrm{Mg}^{2+}$ and $\mathrm{Ca}^{2+}$ ions).

\begin{tabular}{|c|c|c|c|c|c|}
\hline Alloy Finish & $E_{\mathrm{OCP}}(\mathrm{V})$ & $E_{\text {corr }}(\mathrm{V})$ & $E_{\text {pit }}(\mathrm{V})$ & $i_{\text {corr }}\left(\mu \mathrm{A} \cdot \mathrm{cm}^{-2}\right)$ & $v_{\text {corr }}\left(\mu \mathrm{m} \cdot\right.$ year $\left.^{-1}\right)$ \\
\hline AZ31—\#1200 & $-1.721 \pm 0.015$ & $-1.556 \pm 0.012$ & $-1.500 \pm 0.014$ & $10.5 \pm 0.8$ & $234.6 \pm 56.6$ \\
\hline AZ61—\#1200 & $-1.717 \pm 0.014$ & $-1.594 \pm 0.014$ & $-1.509 \pm 0.009$ & $5.5 \pm 0.6$ & $123.9 \pm 40.6$ \\
\hline AZ31-0.25 $\mu \mathrm{m}$ & $-1.674 \pm 0.005$ & $-1.538 \pm 0.008$ & $-1.474 \pm 0.011$ & $4.9 \pm 0.5$ & $112.5 \pm 26.8$ \\
\hline AZ61-0.25 $\mu \mathrm{m}$ & $-1.643 \pm 0.013$ & $-1.505 \pm 0.011$ & $-1.431 \pm 0.011$ & $7.4 \pm 0.6$ & $171.7 \pm 43.4$ \\
\hline
\end{tabular}

\subsection{Electrochemical Impedance Spectroscopy}

Nyquist plots representing the data obtained with EIS for ground and polished samples of AZ31 and AZ61 alloys were analyzed applying equivalent circuits shown in Figure 4. These equivalent circuits consist of resistance of the corrosion environment (solution) $R_{\mathrm{S}}$, the resistance of layer of corrosion products $R_{1}$ and resistance of the magnesium alloy base material $R_{2}$. In some cases, the inductance $L$ was present in the equivalent circuit, according to the character of the obtained Nyquist plot. Constant phase element (CPE) represents capacity formed between the corrosion environment and the corrosion products created on materials surface or the corrosion products and the magnesium alloy, respectively. Polarization resistance $R_{\mathrm{p}}$ values were calculated according to the equations presented under the equivalent circuits in Figure 4.
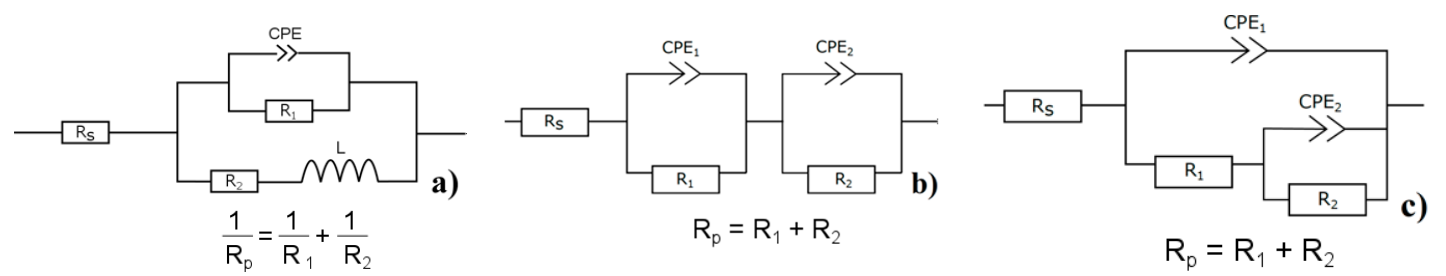

Figure 4. Equivalent circuits used to the evaluation of the obtained Nyquist plots: (a) with an inductive loop in the equivalent circuit, (b) serial connection in the equivalent circuit and (c) parallel connection in the equivalent circuit (CPE: Constant phase element).

Figure 5 shows Nyquist plots characterizing electrochemical corrosion behavior of ground and polished samples of AZ31 and AZ61 alloys. Immersion times of the alloys in the corrosion environment were from $5 \mathrm{~min}$ to $168 \mathrm{~h}$. In all the plots at different immersion times, semicircles at high and low frequencies are present. Obtained impedance data were analyzed using EC-Lab software and best-fitted using the appropriate equivalent circuit model (Figure 4). The determined resulting $R_{\mathrm{p}}$ values are given in Table 5. 

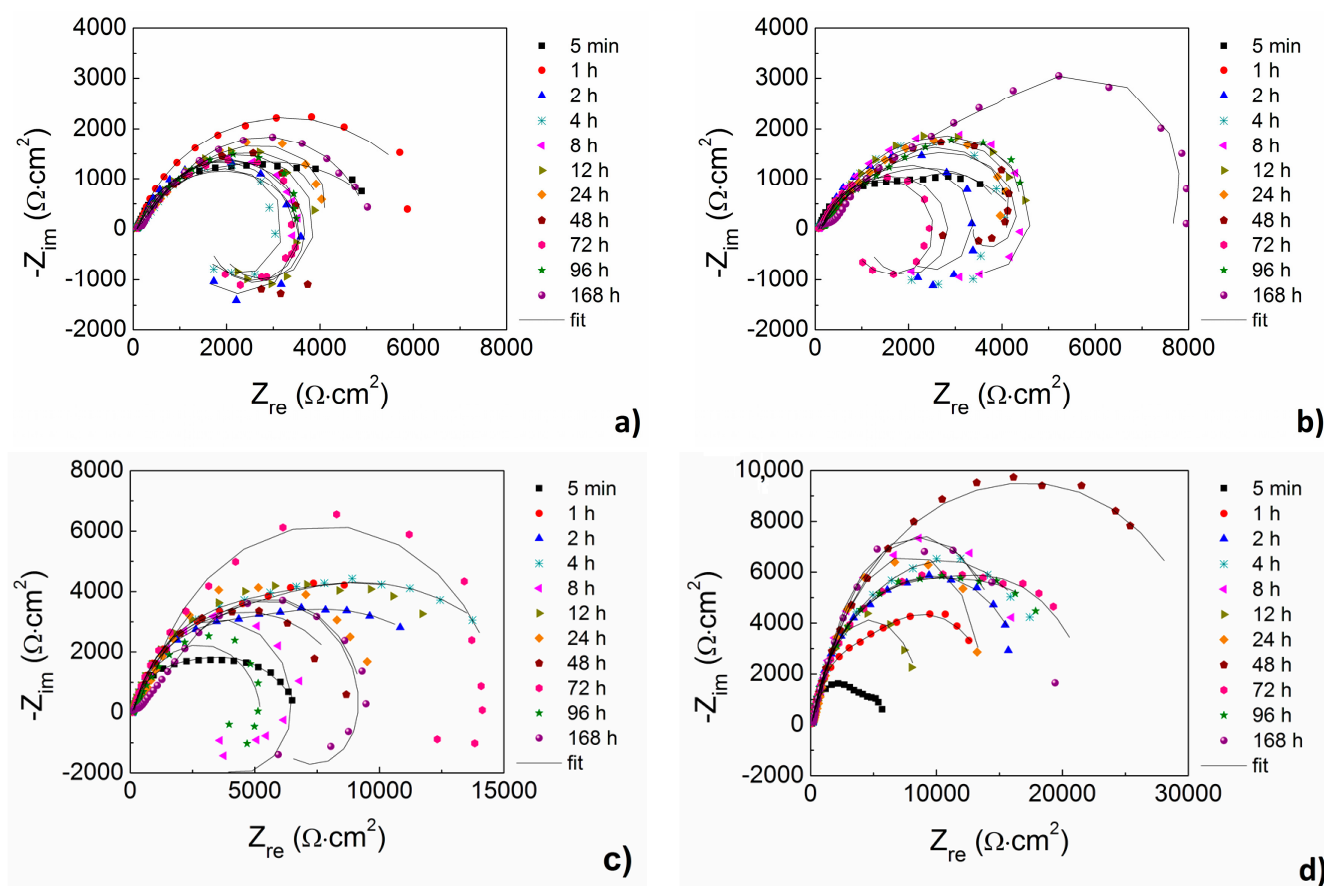

b)

Figure 5. Nyquist plots of ground (\#1200) and polished $(0.25 \mu \mathrm{m})$ samples of AZ31 and AZ61 magnesium alloys obtained in enriched HBSS+ (with $\mathrm{Mg}^{2+}$ and $\mathrm{Ca}^{2+}$ ions): (a) $\mathrm{AZ31}-0.25 \mu \mathrm{m}$, (b) AZ31—\#1200, (c) AZ61—0.25 $\mu \mathrm{m}$ and (d) AZ61—\#1200.

Table 5. Polarization resistance values obtained from EIS (electrochemical impedance spectroscopy) measurements performed in enriched HBSS+ (with $\mathrm{Mg}^{2+}$ and $\mathrm{Ca}^{2+}$ ions).

\begin{tabular}{|c|c|c|c|c|c|c|}
\hline \multirow{2}{*}{ Samples } & \multicolumn{6}{|c|}{$R_{\mathrm{p}}\left(\Omega \cdot \mathrm{cm}^{2}\right)$} \\
\hline & $5 \mathrm{~min}$ & $1 \mathrm{~h}$ & $2 \mathrm{~h}$ & $4 \mathrm{~h}$ & $8 \mathrm{~h}$ & $12 \mathrm{~h}$ \\
\hline AZ31—\#1200 & $5209 \pm 531$ & $3626 \pm 773$ & $3495 \pm 40$ & $3489 \pm 101$ & $3924 \pm 36$ & $5331 \pm 217$ \\
\hline AZ61—\#1200 & $6256 \pm 19$ & $15,458 \pm 31$ & $16,501 \pm 58$ & $18,402 \pm 68$ & $15,509 \pm 333$ & $8800 \pm 564$ \\
\hline $\mathrm{AZ} 31-0.25 \mu \mathrm{m}$ & $4805 \pm 142$ & $6604 \pm 695$ & $3544 \pm 53$ & $3711 \pm 115$ & $3962 \pm 445$ & $5102 \pm 964$ \\
\hline AZ61-0.25 $\mu \mathrm{m}$ & $5916 \pm 37$ & $14,404 \pm 207$ & $12,277 \pm 232$ & $14,203 \pm 33$ & $9193 \pm 280$ & $15,471 \pm 575$ \\
\hline Samples & $24 \mathrm{~h}$ & $48 \mathrm{~h}$ & $72 \mathrm{~h}$ & $96 \mathrm{~h}$ & $168 \mathrm{~h}$ & - \\
\hline AZ31—\#1200 & $5201 \pm 516$ & $4163 \pm 356$ & $2667 \pm 776$ & $4949 \pm 624$ & $7481 \pm 115$ & - \\
\hline AZ61—\#1200 & $27,005 \pm 396$ & $24,392 \pm 768$ & $22,903 \pm 769$ & $22,326 \pm 850$ & $15,691 \pm 2500$ & - \\
\hline $\mathrm{AZ} 31-0.25 \mu \mathrm{m}$ & $4139 \pm 478$ & $4405 \pm 706$ & $3455 \pm 171$ & $3668 \pm 92$ & $4853 \pm 532$ & - \\
\hline AZ61-0.25 $\mu \mathrm{m}$ & $9097 \pm 501$ & $9786 \pm 1020$ & $14,501 \pm 1236$ & $12,693 \pm 126$ & $10,759 \pm 318$ & - \\
\hline
\end{tabular}

\subsection{Characterization of Corrosion Products}

Figure 6 shows the SEM images of the surface of the AZ31 and AZ61 alloys after EIS measurements (168 $\mathrm{h}$ of immersion in enriched HBSS+ with $\mathrm{Mg}^{2+}$ and $\mathrm{Ca}^{2+}$ ions).
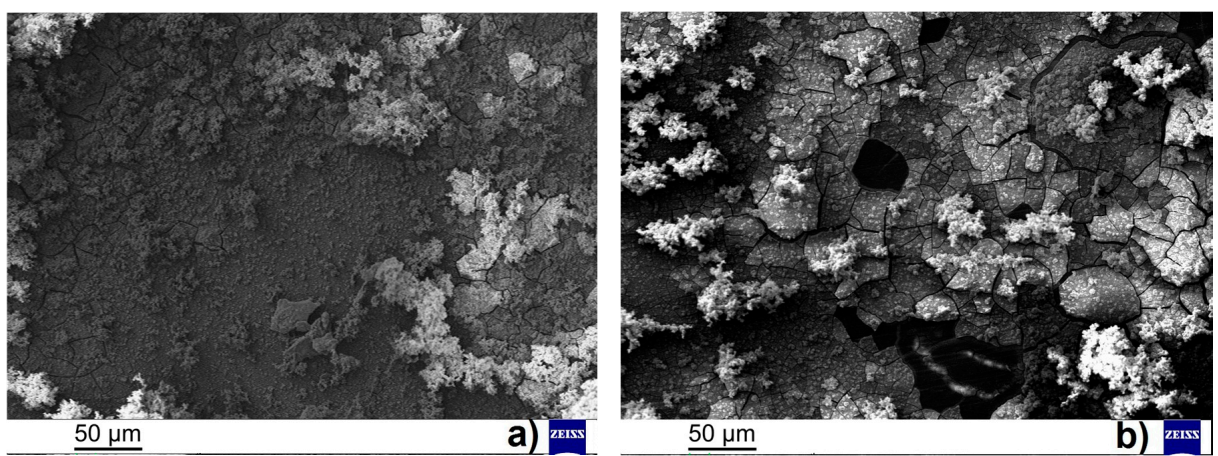

Figure 6. Cont. 

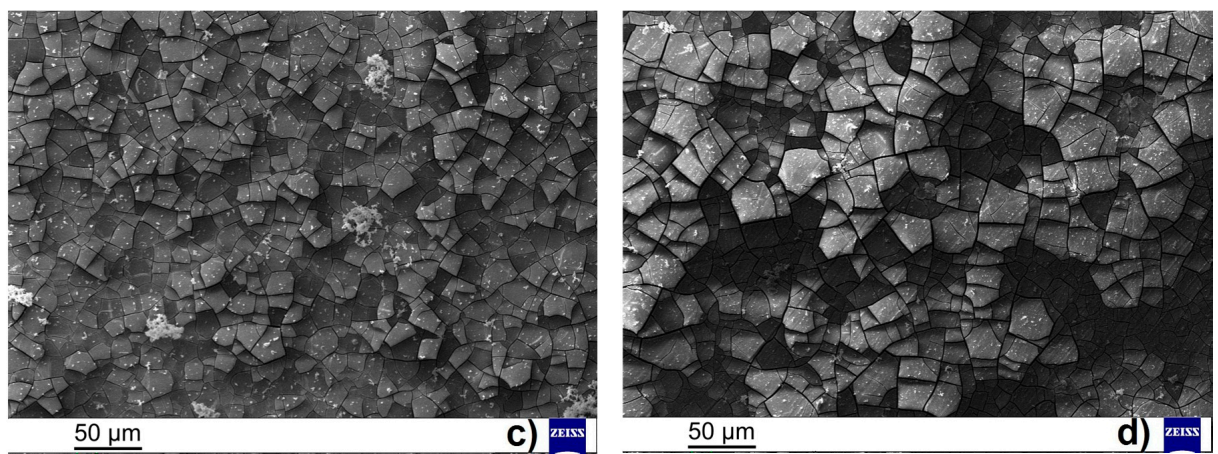

Figure 6. Morphology of the corrosion products present on the surface of tested samples after EIS measurement (168 h of immersion in enriched HBSS+ with $\mathrm{Mg}^{2+}$ and $\mathrm{Ca}^{2+}$ ions): (a) $\mathrm{AZ31}-0.25 \mu \mathrm{m}$, (b) AZ31—\#1200, (c) AZ61-0.25 $\mu \mathrm{m}$ and (d) AZ61—\#1200.

Chemical composition (Table 6) of corrosion products present on the surfaces of the tested samples shows the presence of higher amount of oxygen and phosphorus indicating the presence of phosphates, oxides and hydroxides of magnesium (or calcium respectively).

Table 6. Chemical composition of corrosion product on the surface of AZ31 and AZ61 magnesium alloys after EIS measurements in enriched HBSS+ (with $\mathrm{Mg}^{2+}$ and $\mathrm{Ca}^{2+}$ ions).

\begin{tabular}{cccccccccc}
\hline \multirow{2}{*}{ Samples } & \multicolumn{10}{c}{ Chemical Composition (wt \%) } \\
\cline { 2 - 11 } & Mg & Al & Cl & P & O & C & Na & Ca & S \\
\hline AZ31-\#1200 & 7.3 & 0.3 & 0.3 & 15.3 & 42.8 & 5.5 & 0.4 & 28.0 & 0.1 \\
AZ61-\#1200 & 14.4 & 6.2 & 0.5 & 10.6 & 44.2 & 13.6 & 0.4 & 9.8 & 0.3 \\
AZ31-0.25 $\mu \mathrm{m}$ & 5.1 & 0.1 & 0.2 & 15.6 & 42.4 & 5.0 & 0.4 & 31.1 & 0.1 \\
AZ61-0.25 $\mu \mathrm{m}$ & 14.4 & 4.6 & 0.6 & 11.8 & 43.5 & 11.3 & 0.5 & 13.1 & 0.2 \\
\hline
\end{tabular}

Comparing the surface morphology of AZ31 magnesium alloy with polished and ground surface more pronounced cracking of the layer of corrosion products created on the sample surface can be seen for the ground sample (Figure 6b). The surface of the samples was covered by corrosion products based on $\mathrm{MgO}, \mathrm{Mg}(\mathrm{OH})_{2}[43,44]$ and due to the used corrosion environment also phosphate-based corrosion products [45]. While the amount of $\mathrm{MgO}$ and $\mathrm{Mg}(\mathrm{OH})_{2}$ products is comparable for both the sample surfaces, the phosphate-based layer of corrosion products seems to be thicker for the ground sample (cracked layer presented on the sample surface, below the clusters of $\mathrm{MgO}$ and $\mathrm{Mg}(\mathrm{OH})_{2}$ products).

Significantly smaller amount of $\mathrm{MgO}$ and $\mathrm{Mg}(\mathrm{OH})_{2}$ products were observed on the surface of AZ61 magnesium alloy when compared to AZ31 magnesium alloy. Similarly, as in the case of AZ31 magnesium alloy also in the case of AZ61 magnesium alloy a layer of phosphate-based corrosion products was observed on samples surface. Thicker layer (larger features and cracks) seems to appear on the surface of ground AZ61 magnesium alloy comparing of the polished AZ61 magnesium alloy (Figure 6c,d).

Figure 7 shows the SEM images of the surface of the AZ31 and AZ61 alloys after EIS measurements (168 $\mathrm{h}$ of immersion in HBSS without $\mathrm{Mg}^{2+}$ and $\mathrm{Ca}^{2+}$ ions). 

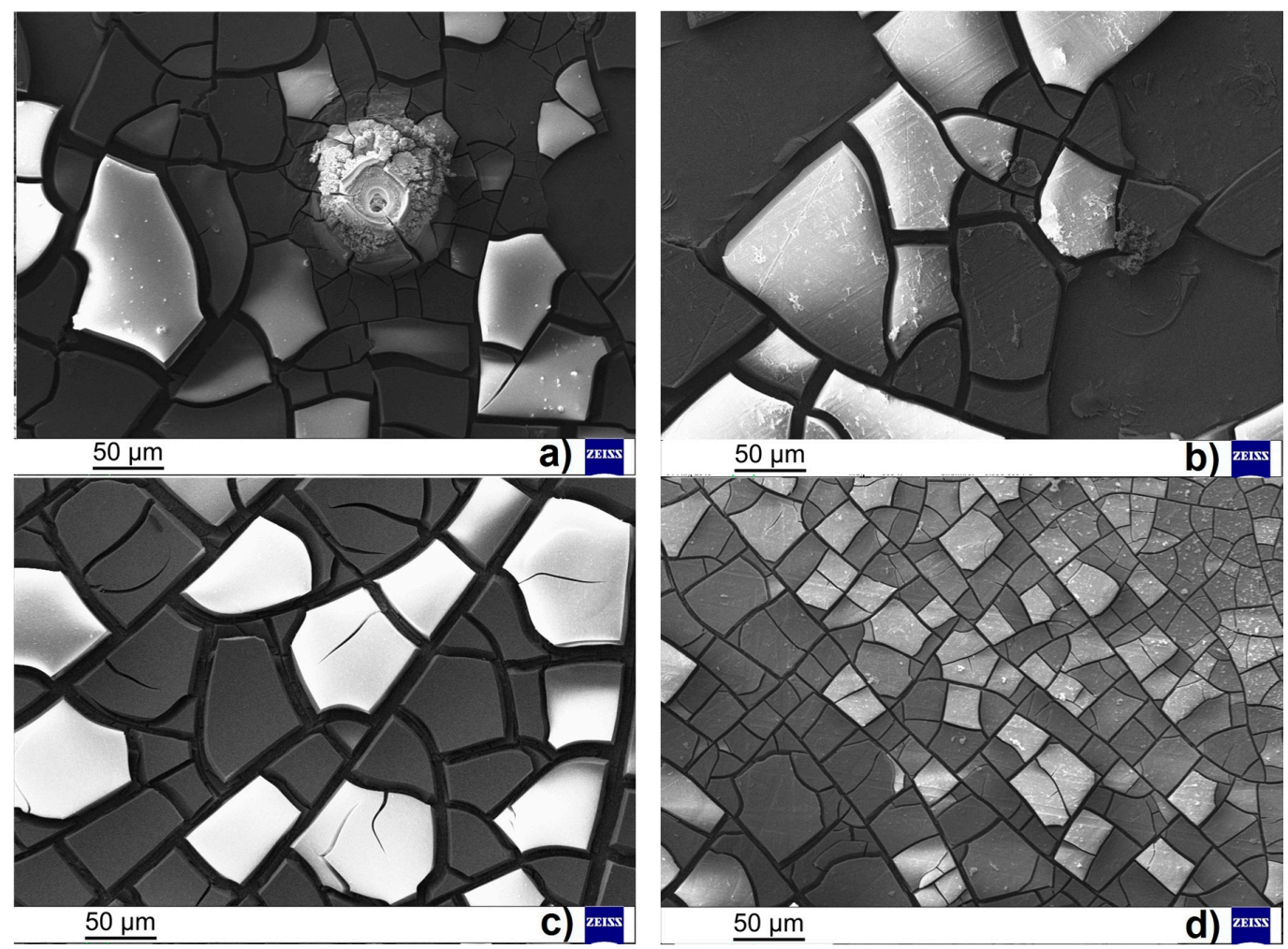

Figure 7. Morphology of the surface after EIS (electrochemical impedance spectroscopy) measurements (168 $\mathrm{h}$ of immersion in HBSS without $\mathrm{Mg}^{2+}$ and $\mathrm{Ca}^{2+}$ ions): (a) AZ31-0.25 $\mu \mathrm{m}$, (b) AZ31-\#1200, (c) AZ61-0.25 $\mu \mathrm{m}$ and (d) AZ61—\#1200.

Chemical composition (Table 7) of corrosion products present on the surfaces of the tested samples from Figure 7 shows the presence of oxygen and phosphorus indicating the presence of phosphates, oxides and hydroxides of magnesium.

Table 7. Chemical composition of corrosion product on the surface of AZ31 and AZ61 magnesium alloys after EIS measurements in HBSS (without $\mathrm{Mg}^{2+}$ and $\mathrm{Ca}^{2+}$ ions).

\begin{tabular}{|c|c|c|c|c|c|c|c|}
\hline \multirow{2}{*}{ Samples } & \multicolumn{7}{|c|}{ Chemical Composition (wt \%) } \\
\hline & $\mathrm{Mg}$ & Al & $\mathrm{Cl}$ & $\mathbf{P}$ & $\mathbf{O}$ & $\mathrm{C}$ & $\mathrm{Na}$ \\
\hline AZ31—\#1200 & 31.4 & 4.1 & 0.8 & 7.7 & 43.2 & 12.1 & 0.7 \\
\hline AZ61—\#1200 & 36.3 & 6.1 & 0.6 & 6.5 & 36.3 & 13.3 & 0.9 \\
\hline $\mathrm{AZ} 31-0.25 \mu \mathrm{m}$ & 35.8 & 4.7 & 0.5 & 7.1 & 37.9 & 13.1 & 0.9 \\
\hline AZ61-0.25 $\mu \mathrm{m}$ & 26.6 & 7.9 & 0.5 & 7.1 & 45.2 & 11.8 & 0.9 \\
\hline
\end{tabular}

The layer of phosphate-based corrosion products was observed on all samples' surfaces. Thicker layer (larger features and cracks) seems to appear on the surface of polished AZ61 magnesium alloy comparing of the ground AZ61 magnesium alloy (Figure 7c,d). In the phosphate-based layer on the AZ31 magnesium alloy surface were regions without any visible corrosion products (Figure $7 \mathrm{~b}$ ). On the polished surface of the AZ31 magnesium alloy (Figure 7a) were moreover present small amount of $\mathrm{MgO}$ and $\mathrm{Mg}(\mathrm{OH})_{2}$ products. 


\section{Discussion}

The effect of the surface treatment (ground vs. polished surface) was observed during potentiodynamic measurements on both types of tested magnesium alloys. In both the cases, more positive value of corrosion potential, $E_{\text {corr }}$ (Table 4$)$, was determined for the polished samples $(0.25 \mu m)$ when compared to the ground samples (\#1200). The microstructure of the AZ61 magnesium alloy contains a higher number of intermetallic phases $\left(\mathrm{Mg}_{17} \mathrm{Al}_{12}\right.$ and $\mathrm{AlMn}$, Figure 2) than the microstructure of the AZ31 magnesium alloy containing only AlMn particles (Figure 1). All of these intermetallic phase particles have more positive potential [46-48] than the substitution solid solution $(\alpha-\mathrm{Mg})$ which caused the formation of microcells which usually result in the acceleration of the corrosion process. The observations are in agreement with [49] where a positive effect of decreasing surface roughness on AZ91 alloy electrochemical corrosion properties was presented. However, authors in [49] performed the EIS measurement only $2 \mathrm{~h}$ of exposure of the material in $0.5 \mathrm{wt} \% \mathrm{NaCl}$ solution and cannot detect the influence of evolution of the layer of corrosion products and its adhesion to the material surface.

The difference in the $E_{\text {corr }}$ values determined for ground and polished surface was more significant in the case of AZ61 magnesium alloy (Figure 8). The grinding process results in the higher roughness of the treated surface comparing to the polished surface resulting in a larger real surface area exposed to the corrosion environment [49]. $E_{\text {corr }}$ reaches more negative value comparing to the polished surface and therefore the ground surface can be considered as less stable from a thermodynamic point of view than the polished surface. While only a small amount of intermetallic phase particles was present in the case of the AZ31 magnesium alloy, the effect of the chemical heterogeneity and surface roughness was smaller compared to the AZ61 magnesium alloy samples. Corrosion potential $E_{\text {corr }}$ of the AZ31 and AZ61 alloys determined from measurements in HBSS without $\mathrm{Mg}^{2+}$ and $\mathrm{Ca}^{2+}$ ions reported by authors in [32] have more negative values than data obtained in enriched HBSS+ with $\mathrm{Mg}^{2+}$ and $\mathrm{Ca}^{2+}$ ions (Figure 8). In the [32] was not observed pitting corrosion attack of the samples (no pitting potential $E_{\text {pit }}$ was observed on the curves) which indicate higher reactivity of tested magnesium alloys in enriched HBSS+ probably caused by the content of $\mathrm{Mg}^{2+}, \mathrm{Ca}^{2+}$ and sulphate ions.

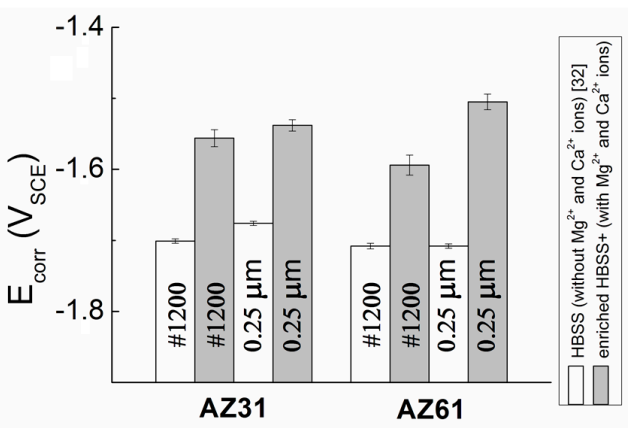

(a)

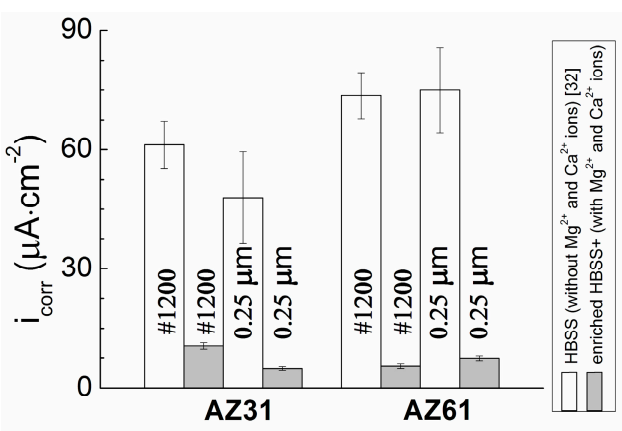

(b)

Figure 8. Comparison of (a) $\mathrm{E}_{\text {corr }}$ and (b) $i_{\text {corr }}$ of ground (\#1200) and polished (0.25 $\left.\mu \mathrm{m}\right)$ surface AZ31 and AZ61 magnesium alloys in enriched HBSS+ (with $\mathrm{Mg}^{2+}$ and $\mathrm{Ca}^{2+}$ ions) and in HBSS (without $\mathrm{Mg}^{2+}$ and $\mathrm{Ca}^{2+}$ ions [32]).

While in the case of AZ31 magnesium alloy a positive effect of polishing on the material response of the corrosion environment from the kinetic point of view can be considered, opposite behavior was observed in the case of AZ61 magnesium alloy. Polishing of the surface of AZ31 alloy resulted in 50\% decrease in the corrosion current density $\left(i_{\text {corr }}\right)$. However, the same treatment resulted in $50 \%$ increase of the $i_{\text {corr }}$ in the case of the AZ61 alloy. However, this behavior can be also explained by the presence on a large amount of intermetallic phase particles in the microstructure of AZ61 alloy and higher real surface area after grinding process. 
Corrosion current density $\left(i_{\text {corr }}\right)$ and the resulting corrosion rate $\left(v_{\text {corr }}\right)$ were higher in the corrosion environment of HBSS without $\mathrm{Mg}^{2+}$ and $\mathrm{Ca}^{2+}$ ions reported in [32] (Figure 8). Comparing to the presented data the differences in the values were mostly about ten times. This effect could be caused by the presence or absence of especially $\mathrm{Mg}^{2+}$ ions in the solution. In the case of HBSS without $\mathrm{Mg}^{2+}$ and $\mathrm{Ca}^{2+}$ ions could play a role the concentration gradient [50-52]. Magnesium in the alloys reacts with the corrosion environment to produce $\mathrm{Mg}^{2+}$ ions. In the beginning of the immersion of the samples no $\mathrm{Mg}^{2+}$ ions are present in the solution. Thanks to the concentration gradient the $\mathrm{Mg}^{2+}$ ions migrate from the place with high concentration place of the ions (the surface of the samples) to the place with low concentration of the ions (HBSS without $\mathrm{Mg}^{2+}$ and $\mathrm{Ca}^{2+}$ ions). This migration of the $\mathrm{Mg}^{2+}$ ions supports reactions of the corrosion environment with the surface of AZ31 and AZ61 alloys. On the other hand, the concentration gradient of the enriched HBSS+ with $\mathrm{Mg}^{2+}$ and $\mathrm{Ca}^{2+}$ ions should be lower compared to the solution without the ions because of the primary presence of the $\mathrm{Mg}^{2+}$ ions in the corrosion environment. The migration of the $\mathrm{Mg}^{2+}$ ions from the surface of the alloys to the corrosion environment is not so fast (like in HBSS without $\mathrm{Mg}^{2+}$ and $\mathrm{Ca}^{2+}$ ions) which reduces a number of the amount of reactions of the corrosion environment with the surface of the magnesium alloys.

This theory is supported by the results presented in $[33,34,36]$. The authors describe the effect of the chlorides and sulphate ions concentration on the corrosion resistance of magnesium alloys. With the increasing content of these ions, the $i_{\text {corr }}$ values increased and $v_{\text {corr }}$, respectively. However, when comparing $i_{\text {corr }}$ values (Figure 8 ) in HBSS and enriched HBSS+, this phenomenon did not occur. Enriched HBSS+ contains more chloride and sulphate ions (Table 1) but $i_{\text {corr }}$ values are lower. Corrosion behavior of magnesium alloys in corrosion environment with sulphate ions is usually measured in sodium sulphate solution [36] where the absence of $\mathrm{Mg}^{2+}$ ions could cause higher reactivity of the alloys.

Potentiodynamic measurements are only short-time measurements. All the measurements take approximately $10 \mathrm{~min}$ ( $5 \mathrm{~min}$ of stabilization time and $5 \mathrm{~min}$ of measurement itself). Therefore, the potentiodynamic measurements are affected by conditions at the beginning of the measurement like the concentration of specific ions in the solution, concentration gradient, etc. Moreover, if the corrosion potential $\left(E_{\text {pit }}\right)$ appear, no Tafel region could be observed in the anodic branch of the polarization curves [38].

From the long-time point of view the corrosion behavior of AZ31 and AZ61 alloys can be characterized by EIS. Electrochemical corrosion behavior of the magnesium alloys in enriched HBSS+ with $\mathrm{Mg}^{2+}$ and $\mathrm{Ca}^{2+}$ ions represented by the evolution of polarization resistance is shown in Figure 9a.

While almost no influence of the surface finish was observed in the case of AZ31 magnesium alloy, higher values of polarization resistance were observed for ground AZ61 magnesium alloy comparing to the polished material state.
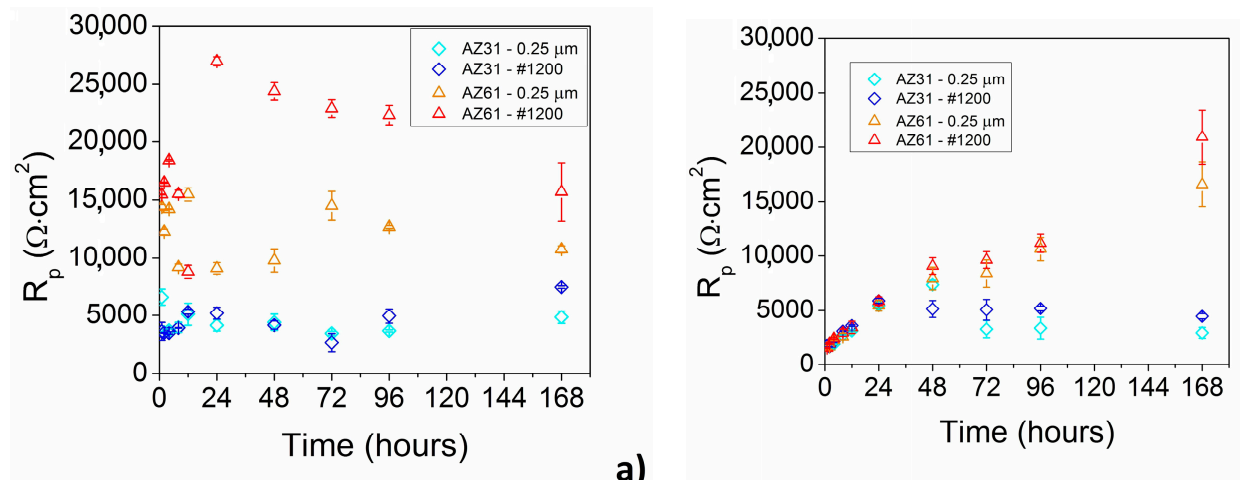

a)

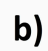

Figure 9. Polarization resistance $R_{\mathrm{p}}$ of ground (\#1200) and polished $(0.25 \mu \mathrm{m})$ surface of AZ31 and AZ61 magnesium alloys: (a) in enriched HBSS+ (with $\mathrm{Mg}^{2+}$ and $\mathrm{Ca}^{2+}$ ions) and (b) in HBSS (without $\mathrm{Mg}^{2+}$ and $\mathrm{Ca}^{2+}$ ions [32]). 
In the case of AZ31 magnesium alloy the values of polarization resistance oscillated around $4000 \Omega \cdot \mathrm{cm}^{2}$ for all the times of measurement for both the material states. The similar resistivity of both the material states can be connected with similar corrosion products (amount and character) observed on material surfaces (Figure 6a,b). On the surfaces of both the analyzed samples was observed the presence of a layer of magnesium phosphate $\left(\mathrm{Mg}_{3}\left(\mathrm{PO}_{4}\right)_{2}\right)$ and hydroxiapatite $\left(\mathrm{Ca}_{10}\left(\mathrm{PO}_{4}\right)_{6}(\mathrm{OH})_{2}\right)$ primarily created on the sample surface and covered by large number of clusters of $\mathrm{MgO}$ and $\mathrm{Mg}(\mathrm{OH})_{2}$ products $[45,53]$. The assumption that the layer of the magnesium phosphate $\left(\mathrm{Mg}_{3}\left(\mathrm{PO}_{4}\right)_{2}\right)$ and hydroxiapatite $\left(\mathrm{Ca}_{10}\left(\mathrm{PO}_{4}\right)_{6}(\mathrm{OH})_{2}\right)$ is thicker (Figure 6) in the case of ground sample correlate with slightly higher values of $R_{\mathrm{p}}$ determined for the material state (Table 5). However, material surface finish did not show any significant influence on AZ31 magnesium alloy corrosion resistivity in enriched HBSS+ with $\mathrm{Mg}^{2+}$ and $\mathrm{Ca}^{2+}$ ions from the long-time point of view.

In the case of ground AZ61 magnesium alloy an increase of $R_{\mathrm{p}}$ up to $24 \mathrm{~h}$ of exposure followed by its decrease back to the value characteristic for the beginning of the experiment was observed (Table 5 and Figure 8a). In the case of polished AZ61 magnesium alloy a decrease of $R_{\mathrm{p}}$ up to $24 \mathrm{~h}$ of exposure, it follows an increase up to $72 \mathrm{~h}$ of exposure followed by an additional decrease to the value lower than the resistance of material on the beginning of the exposure was observed (Table 5 and Figure 8). Higher values of $R_{\mathrm{p}}$ comparing to the AZ31 magnesium alloy can be explained by material higher chemical heterogeneity and thus faster evolution of corrosion products on the material surface. On the other hand, the differences between the polarization resistance of the ground and polished AZ61 magnesium alloy can be corresponding to the higher material surface roughness. Higher real surface area of the rough ground samples can be connected by faster growth of the layer of magnesium phosphate $\left(\mathrm{Mg}_{3}\left(\mathrm{PO}_{4}\right)_{2}\right)$ and hydroxiapatite $\left(\mathrm{Ca}_{10}\left(\mathrm{PO}_{4}\right)_{6}(\mathrm{OH})_{2}\right)$ on sample surface comparing to the polished sample surface. This was also observed in Figure $6 c, d$, where the thicker layer of corrosion products was assumed for the ground sample when compared to the polished sample. The not stable evolution of the $R_{\mathrm{p}}$ in time can correlate with the thicker layer of corrosion products and its cracking, corrosion or remove from the samples surface, which was observed only in a minor form in the case of AZ31 magnesium alloy with the stable evolution of $R_{\mathrm{p}}$ in time. The presence of inductive loop L $[54,55]$ in the equivalent circuit implies the occurrence of pitting corrosion on the magnesium alloy's surface.

The values of polarization resistance $R_{\mathrm{p}}$ are quite high at the beginning of exposition of the samples in the corrosion environment. The values of $R_{\mathrm{p}}$ support the theory of $\mathrm{Mg}^{2+}$ ions concentration gradient as well as in the case of explanation for $i_{\text {corr }}$ change ( $v_{\text {corr }}$ respectively). Magnesium reacts more slowly when $\mathrm{Mg}^{2+}$ ions are present in the corrosion environments as itself (enriched HBSS+ with $\mathrm{Mg}^{2+}$ and $\mathrm{Ca}^{2+}$ ions). Helmholtz double layer created on the interface magnesium alloy/corrosion environment is more stable as in the case of HBSS without $\mathrm{Mg}^{2+}$ ions and the resistance of the material is high.

The opposite phenomenon can be observed in the case of HBSS without $\mathrm{Mg}^{2+}$ and $\mathrm{Ca}^{2+}$ ions. At the beginning of the exposition of the samples to this corrosion environment the $R_{\mathrm{p}}$ values are lower (Figure 9b) than in the case of the enriched HBSS+ with $\mathrm{Mg}^{2+}$ and $\mathrm{Ca}^{2+}$ ions and the value increase with increasing time of exposure to the corrosion environment.

$\mathrm{Up}$ to $24 \mathrm{~h}$ of exposure comparable values of $R_{\mathrm{p}}$ were determined for both the alloys and for both the material states in HBSS without $\mathrm{Mg}^{2+}$ and $\mathrm{Ca}^{2+}$ ions (Figure 9b). With increasing exposure time the values of $R_{\mathrm{p}}$ slowly decreased for AZ31 magnesium alloy, while slightly higher values of $R_{\mathrm{p}}$ were determined for the ground samples. This observation corresponds to the smaller number of cracks in the layer of corrosion products present on the surface of ground samples comparing to the polished samples (Figure 7a,b). An increase of $R_{\mathrm{p}}$ above $24 \mathrm{~h}$ of exposure to the corrosion environment was observed for AZ61 magnesium alloy, while the highest values were determined for $168 \mathrm{~h}$ of exposure to the HBSS without $\mathrm{Mg}^{2+}$ and $\mathrm{Ca}^{2+}$ ions (Figure 9b). Same as in the case of the AZ31 alloy, also in the case of AZ61 alloy slightly higher values of $R_{p}$ were determined for the ground samples. Figure $7 c, d$ showing the surface of the samples after the EIS measurements can exhibit the explanation for this material behavior. While the smaller number of finer cracks were observed on the surface of the layer 
of corrosion products created on the ground sample compared to the deep and large cracks observed on the surface of the polished sample.

In the both corrosion environments, the influence of corrosion products must be taken into account when predicting material corrosion behavior, because magnesium and its alloys are very reactive by themselves. The corrosion layer behaves as a barrier against the further access of corrosion environment to the surface of the magnesium alloys. The layers of the corrosion products are composed mainly of the oxides, hydroxides, phosphates and chlorides [45]. However, the layer is porous and uncompacted (cracks are present in Figures 6 and 7) which leads to other reactions in the corrosion environments of the samples. Even though, different corrosion products are created on the surface of AZ31 and AZ61 alloys due to the chemical composition of the used corrosion solution, more stable material behavior was observed for the AZ31 magnesium alloy samples in both of the solutions. AZ61 magnesium alloy exhibited more stable corrosion response in the HBSS without $\mathrm{Mg}^{2+}$ and $\mathrm{Ca}^{2+}$ ions [32] comparing to its behavior in enriched HBSS+ with $\mathrm{Mg}^{2+}$ and $\mathrm{Ca}^{2+}$ ions.

\section{Conclusions}

This work was focused on the evaluation of corrosion behavior of AZ31 and AZ61 magnesium alloys in enriched HBSS+ (with $\mathrm{Mg}^{2+}$ and $\mathrm{Ca}^{2+}$ ions) by electrochemical methods and the results were compared with results presented in [32]. The results of the work can be summarized as follows:

(1) Electrochemical corrosion properties of AZ31 and AZ61 alloys are dependent on corrosion environment composition.

(2) AZ31 and AZ61 alloys had more positive corrosion potential $E_{\text {corr }}$ and significantly lower values of corrosion current density $i_{\text {corr }}$ in the enriched HBSS+ (with $\mathrm{Mg}^{2+}$ and $\mathrm{Ca}^{2+}$ ions) comparing to the standard HBSS (without $\mathrm{Mg}^{2+}$ and $\mathrm{Ca}^{2+}$ ions). It was also observed that the pitting corrosion attack with pitting potential $E_{\text {pit }}$ in the enriched HBSS+ solution (with $\mathrm{Mg}^{2+}$ and $\mathrm{Ca}^{2+}$ ions) which resulted in less uniform corrosion attack (less predictable material behavior) of the material compared to material behavior in HBSS.

(3) No significant influence of the surface treatment (ground vs. polished) was observed during EIS measurements of AZ31 magnesium alloy performed in both types of the HBSSs.

(4) Polarization resistance $R_{\mathrm{p}}$ of AZ61 magnesium alloy in enriched HBSS+ (with $\mathrm{Mg}^{2+}$ and $\mathrm{Ca}^{2+}$ ions) was affected by surface treatment. $R_{\mathrm{p}}$ values of ground samples were higher than $R_{\mathrm{p}}$ of polished samples, after $24 \mathrm{~h}$ of exposure.

(5) AZ61 magnesium alloy reached higher $R_{\mathrm{p}}$ values than AZ31 magnesium alloy in both the used HBSSs which indicated better corrosion resistivity.

(6) While only phosphate-based corrosion products layer was characteristic for magnesium alloys EIS tested in HBSS, the combination of phosphate-based corrosion products layer and clusters of $\mathrm{MgO}$ and $\mathrm{Mg}(\mathrm{OH})_{2}$ products were presented on the surface of specimens tested in enriched HBSS+ (with $\mathrm{Mg}^{2+}$ and $\mathrm{Ca}^{2+}$ ions).

Acknowledgments: This work was supported by the project "Materials Research Centre at FCH BUTSustainability and Development", REG LO1211, with financial support from National Programme for Sustainability I (Ministry of Education, Youth and Sports), Czech Republic; NETME center plus, projects of Ministry of Education, Youth and Sports of the Czech Republic under the "National sustainability program"; and by the Slovak Research and Development Agency for support in experimental by the projects No. APVV-14-0284, No. APVV-14-0772 and No. APVV-14-0096.

Author Contributions: Jakub Tkacz, Pavel Doležal and Jaromír Wasserbauer conceived and designed the experiments; Karolína Slouková and Jozef Minda performed electrochemical measurements; Jakub Tkacz and Juliána Drábiková performed SEM analysis; Pavel Doležal provided experimental materials; Jakub Tkacz and Stanislava Fintová wrote the paper.

Conflicts of Interest: The authors declare no conflict of interest. 


\section{References}

1. Jung, O.; Smeets, R.; Porchetta, D.; Kopp, A.; Ptock, C.; Müller, U.; Heiland, M.; Schwade, M.; Behr, B.; Kröger, N.; et al. Optimized in vitro procedure for assessing the cytocompatibility of magnesium-based biomaterials. Acta Biomater. 2015, 23, 354-363. [CrossRef] [PubMed]

2. Farraro, K.F.; Kim, K.E.; Woo, S.L.; Flowers, J.R.; McCullough, M.B. Revolutionizing orthopedic biomaterials: The potential of biodegradable and bioresorbable magnesium-based materials for functional tissue engineering. J. Biomech. 2014, 47, 1979-1986. [CrossRef] [PubMed]

3. Mhaede, M.; Pastorek, F.; Hadzima, B. Influence of shot peening on corrosion properties of biocompatible magnesium alloy AZ31 coated by dicalcium phosphate dihydrate (DCPD). Mater. Sci. Eng. C 2014, 39, 330-335. [CrossRef] [PubMed]

4. Gu, X.N.; Zheng, Y.F. A review on magnesium alloys as biodegradable materials. Front. Mater. Sci. China 2010, 4, 111-115. [CrossRef]

5. Witte, F.; Kaese, V.; Haferkamp, H.; Switzer, E.; Meyer-Lindenberg, A.; Wirth, C.J.; Windhagen, H. In vivo corrosion of four magnesium alloys and the associated bone response. Biomaterials 2005, 26, 3557-3563. [CrossRef] [PubMed]

6. Li, W.; Guan, S.; Chen, J.; Hu, J.; Chen, S.; Wang, L.; Zhu, S. Preparation and in vitro degradation of the composite coating with high adhesion strength on biodegradable Mg-Zn-Ca alloy. Mater. Charact. 2011, 62, 1158-1165. [CrossRef]

7. Homayun, B.; Afshar, A. Microstructure, mechanical properties, corrosion behavior and cytotoxicity of Mg-Zn-Al-Ca alloys as biodegradable materials. J. Alloys Compd. 2014, 607, 1-10. [CrossRef]

8. Bakhsheshi-Rad, H.R.; Idris, M.H.; Abdul-Kadir, M.R.; Ourdjini, A.; Medraj, M.; Daroonparvar, M.; Hamzah, E. Mechanical and bio-corrosion properties of quaternary Mg-Ca-Mn-Zn alloys compared with binary Mg-Ca alloys. Mater. Des. 2014, 53, 283-292. [CrossRef]

9. Staiger, M.P.; Pietak, A.M.; Huadmai, J.; Dias, G. Magnesium and its alloys as orthopedic biomaterials: A review. Biomaterials 2006, 27, 1728-1734. [CrossRef] [PubMed]

10. Song, G. Control of biodegradation of biocompatable magnesium alloys. Corros. Sci. 2007, 49, $1696-1701$. [CrossRef]

11. Salleh, E.M.; Zuhailawati, H.; Ramakrishnan, S.; Gepreel, M.A.-H. A statistical prediction of density and hardness of biodegradable mechanically alloyed $\mathrm{Mg}-\mathrm{Zn}$ alloy using fractional factorial design. J. Alloys Compd. 2015, 644, 476-484. [CrossRef]

12. Plum, L.M.; Rink, L.; Haase, H. The essential toxin: Impact of zinc on human health. Int. J. Environ. Res. Public Health 2010, 7, 1342-1365. [CrossRef] [PubMed]

13. Atkins, P. Physical Chemistry, 8th ed.; Freeman and Company: New York, NY, USA, 2006; pp. 1-1053.

14. Gray, J.E.; Luan, B. Protective coatings on magnesium and its alloys-A critical review. J. Alloys Compd. 2002, 336, 88-113. [CrossRef]

15. Song, G.L.; Atrens, A. Corrosion mechanism of magnesium alloys. Adv. Eng. Mater. 1999, 1, 11-13. [CrossRef]

16. Ferero López, A.D.; Lehr, I.L.; Saidman, S.B. Anodisation of AZ91D magnesium alloy in molybdate solution for corrosion protection. J. Alloys Compd. 2017, 702, 338-345. [CrossRef]

17. Kannan, M.B.; Raman, R.K.S. In vitro degradation and mechanical integrity of calcium-containing magnesium alloys in modified-simulated body fluid. Biomaterials 2008, 29, 2306-2314. [CrossRef] [PubMed]

18. Xin, Y.; Hu, T.; Chu, P.K. In vitro studies of biomedical magnesium alloys in a simulated physiological environment: A review. Acta Biomater. 2011, 7, 1452-1459. [CrossRef] [PubMed]

19. Proudfoot, A.T. Aluminium and zinc phosphide poisoning. Clin. Toxicol. 2009, 47, 89-100. [CrossRef] [PubMed]

20. Seitz, J.M.; Eifler, R.; Bach, F.W.; Maier, H.J. Magnesium degradation products: Effects on tissue and human metabolism. J. Biomed. Mater. Res. A 2014, 102, 3744-3753. [CrossRef] [PubMed]

21. Adeknmbi, I.; Mosher, C.Z.; Lu, H.H.; Reihle, M.; Kubba, H.; Tanner, K.E. Mechanical behaviour of biodegradable AZ31 magnesium alloy after long term in vitro degradation. Mater. Sci. Eng. C 2017, 77, 1135-1144. [CrossRef] [PubMed]

22. Li, Q.; Jiang, G.; Wang, C.; Dong, J.; He, G. Mechanical degradation of porous titanium with entangled structure filled with biodegradable magnesium in Hanks' solution. Mater. Sci. Eng. C 2015, 57, 349-354. [CrossRef] [PubMed] 
23. Brar, H.S.; Wong, J.; Manuel, M.V. Investigation of the mechanical and degradation properties of Mg-Sr and Mg-Zn-Sr alloys for use as potential biodegradable implant materials. J. Mech. Behav. Biomed. Mater. 2012, 7, 87-95. [CrossRef] [PubMed]

24. Berglund, I.S.; Brar, H.S.; Dolgova, N.; Acharya, A.P.; Keselowsky, B.G.; Sarntinoranont, M.; Manuel, M.V. Synthesis and characterization of Mg-Ca-Sr alloys for biodegradable orthopedic implant applications. J. Biomed. Mater. Res. Part B Appl. Biomater. 2012, 100, 1524-1534. [CrossRef] [PubMed]

25. Zhang, F.; Ma, A.; Song, D.; Jiang, J.; Lu, F.; Zhang, L.; Yang, D.; Chen, J. Improving in vitro biocorrosion resistance of Mg-Zn-Mn-Ca alloy in Hank's solution through addition of cerium. J. Rare Earths 2015, 33, 93-101. [CrossRef]

26. Johnston, S.; Shi, Z.; Atrens, A. The influence of $\mathrm{pH}$ on the corrosion rate of high-purity Mg, AZ91 and ZE41 in bicarbonate buffered Hanks' solution. Corros. Sci. 2015, 101, 182-192. [CrossRef]

27. Zainal Abidin, N.I.; Rolfe, B.; Owen, H.; Malisano, J.; Martin, D.; Hofstetter, J.; Uggowitzer, P.J.; Atrens, A. The in vivo and in vitro corrosion of high-purity magnesium and magnesium alloys WZ21 and AZ91. Corros. Sci. 2013, 75, 354-366. [CrossRef]

28. Han, G.; Lee, J.-Y.; Kim, Y.-C.; Park, J.H.; Kim, D.-I.; Han, H.-S.; Yang, S.-J.; Seok, H.-K. Preferred crystallographic pitting corrosion of pure magnesium in Hanks' solution. Corros. Sci. 2012, 63, 316-322. [CrossRef]

29. Zeng, R.-C.; Sun, L.; Zheng, Y.-F.; Cui, H.-Z.; Han, E.-H. Corrosion and characterisation of dual phase Mg-Li-Ca alloy in Hank's solution: The influence of microstructural features. Corros. Sci. 2014, 79, 69-82. [CrossRef]

30. Ng, W.F.; Chiu, K.Y.; Cheng, F.T. Effect of $\mathrm{pH}$ on the in vitro corrosion rate of magnesium degradable implant material. Mater. Sci. Eng. C 2010, 30, 898-903. [CrossRef]

31. Bukovinová, L.; Hadzima, B. Electrochemical characteristics of magnesium alloy AZ31 in Hank's solution. Corros. Eng. Sci. Technol. 2012, 47, 352-357. [CrossRef]

32. Tkacz, J.; Slouková, K.; Minda, J.; Drábiková, J.; Fintová, S.; Doležal, P.; Wasserbauer, J. Corrosion behavior of wrought magnesium alloys AZ31 and AZ61 in Hank's solution. Koroze a Ochrana Materiálu 2016, 60, 101-106. [CrossRef]

33. Ambat, R.; Aung, N.N.; Zhou, W. Studies on the influence of chloride ion and $\mathrm{pH}$ on the corrosion and electrochemical behaviour of AZ91D magnesium alloy. J. Appl. Electrochem. 2000, 30, 865-874. [CrossRef]

34. Altun, H.; Sen, S. Studies on the influence of chloride ion concentration and $\mathrm{pH}$ on the corrosion and electrochemical behaviour of AZ63 magnesium alloy. Mater. Des. 2004, 25, 637-643. [CrossRef]

35. Merino, M.C.; Pardo, A.; Arrabal, R.; Merino, S.; Casajus, P.; Mohedano, M. Influence of chloride ion concentration and temperature on the corrosion of Mg-Al alloys in salt fog. Corros. Sci. 2010, 52, 1696-1704. [CrossRef]

36. Shetty, S.; Nayak, J.; Shetty, N. Influence of sulfate ion concentration and pH on the corrosion of Mg-Al-Zn-Mn (GA9) magnesium alloy. J. Magnes. Alloys 2015, 3, 258-270. [CrossRef]

37. Vander Voort, G.F. Metallography, Principles and Practice, 1st ed.; ASM International: Materials Park, OH, USA, 1999; pp. 1-752.

38. Tkacz, J.; Minda, J.; Fintová, S.; Wasserbauer, J. Comparison of electrochemical methods for the evaluation of cast AZ91 magnesium alloy. Materials 2016, 9, 925. [CrossRef] [PubMed]

39. Liu, F.; Song, Y.; Shan, D.; Han, E. Corrosion behavior of AZ31 magnesium alloy in simulated acid rain solution. Trans. Nonferr. Met. Soc. China 2010, 20, 638-642. [CrossRef]

40. Deng, J.; Huang, G.; Zhao, Y.; Wang, B. Electrochemical performance of AZ31 magnesium alloy under different processing conditions. Rare Met. Mater. Eng. 2014, 43, 316-321.

41. Standard Specification for Magnesium-Alloy Sheet and Plate; ASTM B90/B90M-15; ASTM International: West Conshohocken, PA, USA, 2015. Available online: www.astm.org (accessed on 20 October 2017).

42. Standard Specification for Magnesium-Alloy Extruded Bars, Rods, Profiles, Tubes, and Wire; ASTM B107/B107M-13; ASTM International: West Conshohocken, PA, USA, 2013. Available online: www.astm.org (accessed on 20 October 2017).

43. Harandi, S.E.; Banerjee, P.C.; Easton, C.D.; Raman, R.K.S. Influence of bovine serum albumin in Hanks' solution on the corrosion and stress corrosion cracking of a magnesium alloy. Mater. Sci. Eng. C 2017, 80, 335-345. [CrossRef] [PubMed] 
44. Zhu, Y.; Wu, G.; Zhang, Y.H.; Zhao, Q. Growth and characterization of $\mathrm{Mg}(\mathrm{OH})_{2}$ film on magnesium alloy AZ31. Appl. Surf. Sci. 2011, 257, 6129-6137. [CrossRef]

45. Song, Y.; Shan, D.; Chen, R.; Zhang, F.; Han, E.-H. Biodegradable behaviors of AZ31 magnesium alloy in simulated body fluid. Mater. Sci. Eng. C 2009, 29, 1039-1045. [CrossRef]

46. Mathieu, S.; Rapin, C.; Steinmetz, J.; Steinmetz, P. A corrosion study of the main constituent phases of AZ91 magnesium alloys. Corros. Sci. 2003, 45, 2741-2755. [CrossRef]

47. Pardo, A.; Merino, M.C.; Coy, A.E.; Arrabal, R.; Viejo, F.; Matykina, E. Corrosion behaviour of magnesium/aluminium alloys in $3.5 \mathrm{wt} \% \mathrm{NaCl}$. Corros. Sci. 2008, 50, 823-834. [CrossRef]

48. Feliu, S.; Llorente, I. Corrosion product layers on magnesium alloys AZ31 and AZ61: Surface chemistry and protective ability. Appl. Surf. Sci. 2015, 347, 736-746. [CrossRef]

49. Walter, R.; Kannan, M.B. Influence of surface roughness on the corrosion behaviour of magnesium alloy. Mater. Des. 2011, 32, 2350-2354. [CrossRef]

50. Esmaily, M.; Svensson, J.E.; Fajardo, S.; Birbilis, N.; Frankel, G.S.; Virtanen, S.; Arrable, R.; Thomas, S.; Johansson, L.G. Fundamentals and advances in magnesium alloy corrosion. Prog. Mater. Sci. 2017, 89, 92-193. [CrossRef]

51. Zhou, M.; Yan, L.; Ling, H.; Diao, Y.; Pang, X.; Wang, Y. Design and fabrication of enhanced corrosion resistance $\mathrm{Zn}-\mathrm{Al}$ layered double hydroxides films based anion-exchange mechanism on magnesium alloys. Appl. Surf. Sci. 2017, 404, 246-253. [CrossRef]

52. Tian, J.; Huang, H.L.; Pan, Z.Q.; Zhou, H. Effect of flow velocity on corrosion behavior of AZ91D magnesium alloy at elbow of loop system. Trans. Nonferr. Met. Soc. China 2016, 26, 2857-2867. [CrossRef]

53. Zhu, B.; Wang, S.; Wang, L.; Yang, Y.; Liang, J.; Cao, B. Preparation of hydroxyapatite/tannic acid coating to enhance the corrosion resistance and cytocompatibility of AZ31 magnesium alloys. Coatings 2017, 7, 105. [CrossRef]

54. Jayaraj, J.; Raj, S.A.; Srinivasan, A.; Ananthakumar, S.; Pillay, U.T.S.; Dhaipule, N.G.K.; Mudali, U.K. Composite magnesium phosphate coatings for improved corrosion resistance of magnesium AZ31 alloy. Corros. Sci. 2016, 113, 104-115. [CrossRef]

55. Yagi, S.; Sengoku, A.; Kubota, K.; Matsubara, E. Surface modification of ACM522 magnesium alloy by plasma electrolytic oxidation in phosphate electrolyte. Corros. Sci. 2012, 57, 74-80. [CrossRef] 